\title{
Social Europe, Democracy and Brexit
}

\author{
Sandrine Kott
}

In April 2017 the European Commission published its proposal for the European Pillars of Social Rights. This text proposed ' 20 key principles to support fair and well-functioning labour markets and welfare systems', setting the framework for 'equal opportunities and access to the labour market', 'fair working conditions' and 'social protection and inclusion'. This text has widely gone unnoticed. Instead, a large percentage of European citizens - particularly those who vote for populist parties - tend to perceive 'Europe' as an abstract single economic market that supports business but is harsh on people. This perception, reinforced by the economic adjustment programme for Greece in 2010, blames the European single market for promoting neo-liberal and deregulatory practices, and for encouraging the various European states to compete against each other and engage in 'social dumping' at the cost of the welfare of the people. This single European open market is also blamed for promoting migration from low-income countries and thus introducing unfair labour competition to higher income countries.

All these real and perceived problems have nurtured growing scepticism towards 'Europe'; they also contributed to the pro-Brexit vote in the United Kingdom in 2016. But there are some contradictions in this position. Often it is the same people who blame 'Europe' for threatening their national welfare state who, if pressed, would agree that a special 'European social model' exists and that it provides a level of protection and redistribution unmatched anywhere else in the world. These same citizens often proudly carry their European Health Insurance card, which allows them to access better and more effective healthcare in other European countries. The perception of Europe as selfish and dictatorial is tied to a paradox, or a supposed dichotomy of 'the national' versus 'the international', that distorts both European as well as British realities. Since the 1980s British politicians have increasingly dismantled the net of protection and redistribution for their citizens. At the same time, within the Council of the European Union they have opposed most of the regulations proposed by the European Commission, in particular those defining the social sphere and social welfare. Therefore, how can it be that many British citizens make the European Commission responsible for the internal British breakdown and the increasing poverty of large segments of their population, while the British state is still perceived as a protective cocoon? To understand this paradox I will first discuss the complicated historical relationship between the national (including British) and the international (European) levels in the construction and dissemination of the European social model. I will then highlight the role and importance of social rights for the fulfilment of a well-functioning democracy. If nothing else, the prospect of Brexit is an opportunity to address widespread and long-standing misperceptions and inconsistencies.

A historical perspective helps us to do just that. Contrary to popular belief, European welfare states were not invented after the Second World War, and the Beveridge report in the UK was not the first attempt to launch welfare measures. European social policies originated in the nineteenth century; they were conceived as a response to mass poverty, which accompanied the first industrialisation and threatened to erode social and political cohesion. Ultimately, they were a means of integrating the fast expanding group of wage labourers, perceived as a 'dangerous' new class, into the nation state. These nineteenth century social laws did much more than just help and protect the poor: they conveyed an ideal of a healthy and coherent society and were

(c) Cambridge University Press 2019. 
intrinsically linked to the national political project. In the UK these vast reform measures were developed to enhance Victorian society. The first social laws were therefore intensely debated because they went to the core of the concept of the nation.

In the UK, just as in other industrialised countries, the first social policy laws developed along three principles. The labour laws initiated the entire development of social measures; they were already formulated by the first half of the nineteenth century. They sought safeguards for workers against abusive exploitation, initially and particularly for children and women who did not have the right nor the means to publicly voice their claims. These laws established the state as a protector of the weakest in society, even against other social actors (such as parents or husbands). Secondly, social insurance or assistance laws aimed to prevent wage workers from falling into depths of misery, from becoming dependent on communal public assistance in case of sickness, invalidity or unemployment. These laws conveyed the idea that national solidarity was the prerequisite for a peaceful society and the dignity of each of its members. Thirdly, at the end of the nineteenth century, several legislative measures tried to regulate employment relations between employers and workers. By encouraging social dialogue and social partnership, liberal socialist, as well as Christian social thinkers promoted a more unified and reliable society based on social democracy. These three principles still define contemporary social states, though in unequal ways. It is, however, important to understand that they do not only offer 'welfare' but are also at the core of the entire notion of citizenship, and as such are instrumental to the smooth functioning of democratic societies.

At the end of the nineteenth century these social measures almost exclusively concerned wage workers, which still constituted a small but growing part of the population. Peasants, who were by far the largest population group in Europe, were neither included in the insurance schemes nor protected by labour laws. Moreover, the redistributive dimension of these measures was still very modest; social expenses did not exceed 4 per cent in Germany, or even 1 per cent in France and Italy, of the total state expenditures. Nevertheless, these measures were important because they granted rights to workers - rights which could and later would be claimed by other groups. These rights were guaranteed by states and contributed to the integration of workers into the national entities. The first social states were therefore explicitly national in outlook and proudly advertised by state officials, civil servants and employees in charge of implementing social laws. In numerous international conferences and congresses, national representatives promoted their own national welfare solutions, which, they claimed, mirrored the very spirit of their nations themselves. Until this point the differences between national institutions in charge of realising these measures made a convergence of welfare systems in Europe almost impossible. This fact was subsequently enshrined in the European 'principle of subsidiarity', which leaves national states to act as complete sovereign in regard to measures introduced into the social field.

However, and here the paradox manifests itself again, most social measures developed during the nineteenth century were not strictly national. They were being discussed in international, often European, spaces by intellectuals, civil servants, employers and reformist trade unionists. Among the social activists involved in these debates were many British women, for example, who became involved as a way to gain their own citizens' rights. The first arguments in favour of European-wide social regulations were already raised in the 1830 s by French and British sociallyminded employers, who maintained that social protections should be 'European' to ensure fair concurrence between the various countries. In 1900 the International Association for Labour Legislation met in Paris and was made responsible for the harmonisation of the policies of different European countries. A permanent office was set up in 1901 in Berne, Switzerland, which was tasked with the circulation of information concerning various national legislations, and to promote and coordinate protective measures in order to guarantee the future compatibility of European social laws. In 1919 this 'voluntary' association gave way to the 'official' International Labor Organization (ILO), the design of which was largely based on a British plan. In the interwar years the ILO, by then recognised as a successful French-British joint venture, 
succeeded in developing an international (in fact, a European) labour and social code in the form of international conventions and recommendations. But these international regulations still needed to be ratified nationally to become compulsory; at the same time, national states remained entirely sovereign in the introduction of social policies.

If the ILO was instrumental in first defining what could be called a 'European social model', we also have to remember that it was established to compete against and prevent the spread of other conceptions of social policies regarded as authoritarian and threatening to the liberal democratic model of society. Firstly, the reformist model of the ILO was promoted against the revolutionary solutions of the Bolsheviks. Secondly, it was promoted against the fascist and Nazi authoritarian and corporatist social state actions. In the 1920s, and again during the Second World War, the ILO favoured a Europe-wide model of social dialogue and self-administered insurance schemes and made the extension of social rights a prerequisite for the stability of political democracy. The clear association between social rights and democracy was strongly reaffirmed in 1941 in the Atlantic Charter. The ILO advertised the Beveridge report as an international welfare model in the context of the war against Nazi social imperialism - and yet it did not follow its own social democratic path. The UK social security system was administrated by the state and not by social partners; it guaranteed low minimal funds, which had to be supplemented from private sources. The British sociologist Thomas Humphrey Marshall, often considered an early and leading theoretician and advocate of the social democratic welfare state model, emphasised the role of social rights as a welcome addition to civil and political rights in his essay Citizenship and the Social Class. But he did not consider them a pre-condition for a well-functioning democracy. These features, which at first went unnoticed, would go on to contribute to the weakening of the very foundations on which the modern British welfare state was established. But during the Cold War this social-democratic narrative first fulfilled a specific function that stressed a middle-way taken by Western Europe, between the US attitude of 'laissez-faire' and the Eastern European welfare dictatorships. In fact, the first decades of the Cold War saw the heyday of the 'European social model' and became a period of steadily increasing welfare expenditures in all European countries. The UK was no exception. But the unevenness of social welfare continued: Scandinavian countries were at the forefront and offered the most universal and costly systems, whereas large parts of the populations in southern Europe, in particular in the Spanish and Portuguese authoritarian regimes, remained unprotected. By the 1970 though, almost 70 per cent of the Western European population enjoyed some kind of public insurance schemes and labour protection.

Because social benefits and protection were successfully implemented in all European countries, and were nurtured by a European conversation, we commonly speak of a 'European social model'. But in the founding treaties and texts of all Western European regional organisations welfare provisions and social protection were marginalised, although not totally absent. 'Social provisions' were enclosed in the founding Treaty of the European Community in 1957 as concessions to member states like France, which were lobbying for greater social coordination and convergence, but some governments, like that of West Germany, opposed more European social regulation. The Social Charter adopted in 1961 by the Council of Europe asserted that every effort should be made 'to improve that standard of living and to promote the social wellbeing ... by means of appropriate institutions and action'. But yet again, the enforcement of this Charter was left to national governments. The European treaties, such as the Charter just mentioned, aimed first to establish the conditions for the creation of an economic open market, which would, in the end, guarantee more prosperity and benefit all: the social measures suggested in these treaties were primarily seeking the facilitation of the circulation of persons and goods within an open, European market. Nevertheless, we should not forget that these treaties articulated the expectations of national governments. As a result of these attitudes, the European Regional Development Fund (created in 1975) allowed for solidarity between European regions but not for that between social classes within Europe. The level of social redistribution, always 
determined by national governments, could thus easily stand at odds with the ever greater interdependence of European economies.

The race between the two competing models of 'good society' during the Cold War era - that of social democracy and that of Soviet communism - played a significant role in the constant increase of social expenditures in Western and Eastern European countries. But the end of the communist regimes in the East and the long decline of communist parties in the West weakened the social pact, which lay at the heart of the European social model. Already during the 1980s conservative European political leaders, particularly the British Prime Minister Margaret Thatcher, decided to destroy trade union resistance, reduce public expenditures and lower the level of labour protection. Politicians like Thatcher argued that excessive trade union power and social measures inhibited economic dynamism and were responsible for economic crises. This fundamental questioning of the social state has never ceased. The Mont Pélerin society or German ordo-liberalism, for instance, have always promoted an economic and political model that aims to reduce social provision to a minimum so as to enhance economic competitiveness. In the new context of the 1980s, in order to make themselves less vulnerable to social criticism, these politicians blamed 'Brussels', the metonym for the European Union and its institutions, for social conflicts or social disarray, even though throughout its history 'Brussels' has never been in charge of social redistribution. On the contrary, as we have seen, European institutions have regularly issued recommendations in favour of more social dialogue and greater protection of democratic societies. For its part, the liberal British model has for a long time conceptualised political democracy as independent of social justice, and consequently British political leaders have weakened the basis of the welfare state without taking into account that this could endanger democracy itself. They have forgotten that democracy is fragile, that it is not only built on solid institutions but also needs a coherent, inclusive and not too unequal society. They also have forgotten that social rights are not optional but constitute the very condition of democracy. Such disregard has opened the doors to populism and to Brexit. Given the long history of connections between national and European welfare It is hard to believe that leaving Europe, and the 'European social model' it promotes, will guarantee British citizens the welfare protection to which they aspire. 